\title{
A Preliminary Study on Gender Differences in Studying Systems Analysis and Design
}

\author{
Fion S.L. Lee ${ }^{*}$, Kelvin C.K. Wong \\ Department of Computer Science, Hong Kong Baptist University, China
}

Copyright $\bigcirc 2017$ by authors, all rights reserved. Authors agree that this article remains permanently open access under the terms of the Creative Commons Attribution License 4.0 International License

\begin{abstract}
Systems analysis and design is a crucial task in system development and is included in a typical information systems programme as a core course. This paper presented a preliminary study on gender differences in studying a systems analysis and design course of an undergraduate programme. Results indicated that male students outperformed female students in general in this course. However, regarding the different study focuses of the course, female students performed better in information systems development methodologies and systems analysis, whereas male students worked better in systems design. Discussions have been raised to explain the findings and it was suggested longitudinal studies could be conducted for a more generalized conclusion.
\end{abstract}

Keywords Systems Analysis and Design, Gender Difference, Undergraduate Education

\section{Introduction}

Systems analysis and design are the complex and challenging activities that take place in information systems development. In the early years of computing, these activities were considered as an art. Nowadays, various methodologies have been developed to make systems analysis and design a disciplined process. With the aim of preparing students majoring information systems for employment, the IS 2010 Curriculum Guidelines for Undergraduate Programs in Information Systems developed by the Association for Computing Machinery (ACM) and the Association for Information Systems (AIS) identified the systems analysis and design course as a core in an IS undergraduate curriculum [1,2].

Many studies have been conducted to enhance student learning in this course. Tepper [3], Oh Navarro and van der Hoek [4], Baker el at. [5] and Hainey el at. [6] examined the use of game-based learning (GBL) approaches to enhance student learning. Other than GBL, many researchers investigated the use of other means such as cross-disciplinary project groups [7], service learning projects [8] and activity diagrams [9] to improve student learning.

Besides student learning enhancement, some studies have addressed gender differences related to information systems. Wilson [10] attended the under-theorization of gender within the information systems literature by adopting a critical and feminist approach to the organizational and broader societal context of information systems development and implementation. Beyer [11] examined the reasons for women's underrepresentation in majoring management information systems. Lenard el at. [12] explored the gender differences in performance in the Accounting Information Systems course. However, they focused on assessing the students' IT skills rather than the systems analysis and design skills. Another study also showed student background, e.g. gender, would affect the collaborative work in a computer network project [13]. It is suggested that gender may have impact in teamwork and in a system development project, tasks could be divided according to different genders for a better result. Though a substantial body of information systems research exists, studies examining the effect of gender on the student performance in systems analysis and design courses are still rare. This study aims to investigate the gender differences in learning information system development methodologies, systems analysis and systems design.

\section{The Study}

This study examined the performance differences between male students and female students in an undergraduate course, Systems Analysis and Design, which is one of the year 3 core courses in the Information Systems and Computing programme. The aim of this course is to teach students some methodological approaches to the development of properly designed and documented information systems with focus on object-oriented analysis and design. 
The study population included 25 students of which 16 and 9 were male and female respectively. The measurement instruments used for this study included four quizzes, one mid-term test and one final examination. Students were required to sit for all assessments individually under a closed book setting. Table 1 shows the question formats and score distribution of each assessment type. The quiz and mid-term test consisted of multiple choice questions and short/conventional questions while the final examination only comprised of conventional questions. Marks will be deducted for the wrong answers given in multiple choice questions, but no deduction for the unattempted questions.

Table 1. Assessment question type and mark distribution

\begin{tabular}{|c|c|c|c|c|}
\hline \multirow{2}{*}{$\begin{array}{c}\text { Assessment } \\
\text { type }\end{array}$} & $\begin{array}{c}|c| \\
\text { Multiple } \\
\text { choice } \\
\text { questions }\end{array}$ & $\begin{array}{c}\text { Short } \\
\text { questions }\end{array}$ & $\begin{array}{c}\text { Conventional } \\
\text { questions }\end{array}$ & $\begin{array}{c}\text { Total } \\
\text { mark }\end{array}$ \\
\hline Quiz & 15 & 10 & 70 & 25 \\
\hline Mid-term test & 30 & & 100 & 100 \\
\hline $\begin{array}{c}\text { Final } \\
\text { examination }\end{array}$ & & & 100 \\
\hline
\end{tabular}

\section{Results and Discussion}

The course consisted of six summative assessments. They were four quizzes, one mid-term test and one final examination. Table 2 shows their achievement mean scores by gender. The full mark was shown inside the brackets in the heading. The quiz mean score was the mean of the total of the four quizzes. Results showed that male students got higher means in all assessments than female students.

Table 2. Achievement means score in assessments by gender

\begin{tabular}{|c|c|c|c|c|}
\hline & $\mathrm{N}$ & $\begin{array}{c}\text { Quiz } \\
(100)\end{array}$ & Test (100) & Examination (100) \\
\hline Male & 16 & 58.91 & 64.13 & 63.44 \\
\hline Female & 9 & 55.89 & 60.50 & 60.72 \\
\hline Total & 25 & 57.82 & 62.82 & 62.46 \\
\hline
\end{tabular}

Though the male students outperformed the female students on the whole, the authors were interested in studying if there was any gender difference in the performance of the three major areas covered by the course, namely, information system development methodologies, systems analysis and systems design. In view of this, the student performance in the final examination was further analyzed as this assessment covered all three areas. The findings were displayed in Table 3.

Table 3. Achievement score in final examination by gender

\begin{tabular}{|c|c|c|c|c|}
\hline & $\mathrm{N}$ & Q.1 (12) & Q.2-4 (45) & Q.5-8 (43) \\
\hline Male & 16 & 5.75 & 31.94 & 25.75 \\
\hline Female & 9 & 7.28 & 32.06 & 21.39 \\
\hline Total & 25 & 6.30 & 31.98 & 24.18 \\
\hline
\end{tabular}

Female students performed significantly better $(\mathrm{p}<0.05)$ than male students in Question 1 which assessed students' knowledge on information systems development methodologies. A possible explanation may lie in the learning approaches. This question did not require students to have prior knowledge, which would "anchor" newly learned concepts and form the basis of an interrelated network of understanding. According to Ausubel [14], students may make use of rote learning in this topic and the literature reported that more females tended toward using rote learning than males $[15,16]$. Hence, female students outperformed male students in this question.

Systems analysis is another major topic in this course. Three questions (Q.2-4) were set to assess students' performance in this topic. The scores of these three questions were aggregated in the analysis. Table 3 reveals that female students had a slightly higher mean score than male students. Since the difference is not significant, attribution to chance may be one of the explanations. Another possible explanation may be due to the gender difference in learning styles. Heffler [17] proposed four learning styles: concrete experience, active experimentation, reflective observation and abstract conceptualization. Studies suggested that there was gender difference in concrete experience and abstract conceptual learning styles $[17,18]$. Females scored higher in concrete learning style whereas males scored higher on the abstract conceptual style. Females with concrete experience learning approach usually are people oriented [17] and be very good at understanding people and identifying problems [19]. This learning style fits the traits to complete the systems analysis task which is people oriented. It requires obtaining information from the users of the current and future information system and identifying the problems in the current system.

Four questions (Q.5-8) were set to evaluate students' understanding in systems design. The scores of these four questions were totaled in data analysis. Table 3 indicates that male students outperformed the female students in terms of mean score. Systems design focuses on the technical concerns of the future system. Its deliverables represent the system specifications for implementing a computer-based solution. As discussed above, males prefer more to abstract conceptual learning style. People with this style enjoy working with symbols and like structure [17]. A study conducted by Heerwegh et al. [20] depicted females feel less control of using computer than males. Other studies found that male have more interest in mechanical workings of computers or experience in programming than females and females had lower computer self-efficacy and thought computing tasks would be more difficult for them [21, 22]. All these findings indicate that males are more appropriate to systems design work which involves the production of the technical system specifications for building the information system. This may explain why male students performed better than female students in systems design questions.

Regardless of the small sample size, these findings can be 
considered as preliminary and provide an insight for future studies. Similar researches can be repeated in the subsequent academic years and at another university or across several institutions in order to confirm the findings. As discussed above, the gender differences in learning styles may explain their differences in performance in different topics of the course. Future studies may be conducted to explore pedagogical methods, taking gender differences in learning styles into consideration, which would enhance the learning experience for all students. The findings of this paper also suggest the division of labor among different genders in a system development project could create a more effective result.

\section{Conclusions}

The current study examined the gender differences in student performance in an undergraduate systems analysis and design course. It was found that male students outperformed female students in general in this course. However, regarding the different study focuses of the course, female students outperformed male students in information systems development methodologies and performed slightly better in systems analysis while male students performed better in systems design. These differences may be due to their differences in learning styles. Despite the limitation of small sample size in the study, it is the authors' aspiration that these findings can be exploited to explore teaching methodologies to reduce the gender differences in learning systems analysis and design.

\section{REFERENCES}

[1] Topi, H., Valacich, J. S., Wright, R. T., Kaiser, K. M., Nunamaker, Jr., J.F., Sipior, J. C. and de Vreede, G. J. (2010). IS 2010 Curriculum Guidelines for Undergraduate Programs in Information Systems, Association for Computing Machinery and Association for Information Systems.

[2] Guidry, Brandi N., Stevens, David P. and Totaro, Michael W. (2011). The systems analysis and design course: an educators' assessment of the importance and coverage of topics. Journal of Information Systems Education; 22(4), 331-345.

[3] Tepper, J. A. (2014). Assessment for learning systems analysis and design using constructivist techniques. The Higher Education Academy.

https://www.heacademy.ac.uk/resources/detail/resources/det ail/stem-conference-2014/Post event_resources/Computing/ Assessment_for (accessed 30 January 2017)

[4] Oh Navarro, E. and van der Hoek, A. (2008). On the role of learning theories in furthering software engineering education. In H.J.C. Ellis, S.A. Demurjian, and J.F. Naveda (Eds), Software Engineering: Effective Teaching and Learning Approaches and Practices, IGI Global.
[5] Baker, A., Oh Navarro, E. and van der Hoek, A. (2005). An experimental card game for teaching software engineering processes. The Journal of Systems and Software, 75, 3-16.

[6] Hainey, T., Connolly, T.M., Stansfield, M.H. and Boyle, E.A. (2011). Evaluation of a game to teach requirements collection and analysis in software engineering at tertiary education level. Computers and Education, 56(1), 21-35.

[7] Surendran K., Ehie Ike C. and Somarajan C. (2005). Enhancing student learning across disciplines: a case example using a systems analysis and design course for MIS and ACS majors. Journal of Information Technology Education, 4, 257-274.

[8] Chuang, K.W. and Chen, K.C. (2013). Designing service learning project in systems analysis and design course. Academy of Educational Leadership Journal, 17(2).

[9] Lending, D and May, J. (2013). Teaching tip using activity diagrams to model systems analysis techniques: teaching what we preach. Journal of Information Systems Education, 24(2), 91-97.

[10] Wilson, M. (2004). A conceptual framework for studying gender in information systems research. Journal of Information Technology, 19, 81-92.

[11] Beyer, S. (2008). Gender differences and intra-gender differences amongst management information systems students. Journal of Information Systems Education, 19(3), 301-310.

[12] Lenard, M. J., Wessels, S. and Khanlarian, C. (2010). Gender differences in attitudes toward computers and performance in the accounting information systems class. American Journal of Business Education, 3(2), 23-29.

[13] Konak, A., Kulturel-Konak, S., Nasereddin, M. and Bartolacci. M. R. (2017). Impact of Collaborative Work on Technology Acceptance: A Case Study from Virtual Computing. Journal of Information Technology Education: Research, 16, 15-29.

[14] Ausubel, D. P. (1963). The Psychology of Meaning Verbal Learning. New York: Grune \& Stratton.

[15] Ridley, D. R. and Novak, J. D. (1983). Sex-related differences in high school science and mathematics enrollments: Do they give males a critical head start toward science- and math-related careers? The Alberta Journal of Education Research, 24, 308-318.

[16] Cavallo, A. M. L. (1994). Do females learn biological topics by rote more than males? The American Biology Teacher, 56, 348-352.

[17] Heffler, B. (2001). Individual learning style and the learning style inventory. Educational Studies, 27(3), 307-316.

[18] Tindall, T. and Hamil, B. (2003). Gender disparity in science education: the causes, consequences, and solution. Education, 125(2), 282-295.

[19] Lachenmayer, D. (1997). Learning styles: a handbook for teachers to identify and teach to all learning styles. M.Ed. dissertation in curriculum and instruction for Pennsylvania State University Graduate School.

[20] Heerwegh, D., De Wit, K. and Verhoeven, J. C. (2016). Exploring the Self-Reported ICT Skill Levels of Undergraduate Science Students. Journal of Information Technology Education: Research, 15, 19-47. 
[21] Beyer, S. (2014). Why are women underrepresented in Computer Science? Gender differences in stereotypes, self-efficacy, values, and interests and predictors of future CS course-taking and grades. Computer Science Education, 24(2-3), 153-192.
[22] He, J. and Freeman, L. A. (2010). Are men more technology-oriented than women? The role of gender on the development of general computer self-efficacy of college students. Journal of Information Systems Education, 21, 203-212. 